\title{
TP53 NP_000537.3:p.R248W
}

National Cancer Institute

\section{Source}

National Cancer Institute. TP53 NP 000537.3:p.R248W. NCI Thesaurus. Code C146906.

A change in the amino acid residue at position 248 in the cellular tumor antigen p53

protein where arginine has been replaced by tryptophan. 